\title{
ANTI- FUNGAL PROPERTIES OF SYNTHESIZED COMPLEXES OF TRIVALENT TRANSITION METAL IONS DERIVED FROM INDAN-1, 3-DIONE AND DIAMINOBENZENE
}

\author{
Rimpi Mehani ne'e Chopra \\ Department of Chemistry, Ramgarhia Girls College, Ludhiana \\ E-mail: rmehani@yahoo.com
}

\begin{abstract}
Macrocyclic ligands and their metal complexes are being synthesized very fast as it is a developing area of research in bioinorganic and inorganic chemistry. A new series of trivalent chromium, cobalt and iron complexes have been prepared through template methods with 2, 2-dihydroxyindane- 1, 3-dione and isomeric diaminopyridines and effectiveness towards anti fungal properties of these complexes is studied against the cotton plant fungi, Alternaria alternata and Fusarium oxysporum. The complexes have been characterized by elemental analyses, molar conductance, electronic spectra, magnetic measurements and IR spectral data which points towards a distorted octahedral geometry. Conductivity measurements in dimethylsulphoxide indicated them to be 1:2 electrolytic in nature (130-170 $\left.\mathrm{ohm}^{-1} \mathrm{~cm}^{2} \mathrm{~mol}^{-1}\right)$. Indofil M-45 and bavistin are the standard fungicides which are used to compare the anti-fungicidal properties of the synthesized complexes. Some of the complexes have been found to be antifungal in nature.

Keywords: 2, 2-Dihydroxyindane-1, 3-dione, ED50 values, Electronic spectra, Efficacy Octahedral, Potato dextrose agar, Magnetic moments.
\end{abstract}

(c) RASĀYAN. All rights reserved

\section{INTRODUCTION}

The recent work on macrocycles and their complexes is the extension of the previous work. The chemistry of transition metal macrocyclic complexes has undergone incredible growth in their synthesis and characterization in the recent years ${ }^{1-5}$. Their easy production, easy release of the metal ion has made this branch of the chemistry very useful for the human race. Transition metal macrocyclic complexes resemble with some compound produced by nature: like natural proteins ${ }^{6}$, hence metallo-enzymes have received much attention ${ }^{7,8}$. As a simple polydentate ligand, the donor atoms in macrocyclic ligands are normally spaced so that on co-ordination five, six and occasionally seven membered chelate rings are formed with a metal which makes their practical application easy ${ }^{9}{ }^{10}$. Catalysis is one field where these complexes are very useful ${ }^{11}$. Some of the pthalocyanines have been shown to behave as a catalyst in a variety of chemical transformations. They also act like semiconductors. Most of the work till date is centered on an open chain, bi-, tri-, tetra- or multidentate ligands ${ }^{12,13}$. Such types of reactions yield complexes of various multidentate open chain ligands. These were the genius efforts of N.F. Curtis ${ }^{14}$ who was first to isolate them. A class of macrocyclic antibiotic called nonacetin, binds with potassium and acts as a carrier for $\mathrm{K}^{+}$to transfer it across the lipid bilayers in the cell membrane. Nitrogencontaining macrocycles have a strong tendency to form stable complexes with transition metals hence this effort was done to prepare some new Nitrogen containing macrocycles.

\section{EXPERIMENTAL}

All synthesis was done by template method. To a stirring methanolic solution $(\sim 100 \mathrm{ml})$ of 1, 2-/1, 3diaminobenzene $(\sim 10 \mathrm{mmol})$ was added trivalent chromium, iron and cobalt (cobaltous chloride was added to $50 \mathrm{ml}$ of $20 \%$ hydrogen peroxide in faintly acidic solution, the solution was heated for half an hour) salts $(\sim 5 \mathrm{mmol})$ dissolved in minimum quantity of methanol. The resulting solution was refluxed for half an hour. Thereafter, ninhydrin $(10 \mathrm{mmol})$ was dissolved in methanol $(\sim 20 \mathrm{ml})$ and added to the 
refluxing mixture and refluxing was continued for 8-10 h, depending upon the metal salts. The mixture was concentrated to half of its original volume and kept in a desiccator for two days. The complexes were filtered, washed with methanol, acetone, and ether and dried in vacuo. (Yield 40-65\%). The purity of the complexes was checked by TLC. The complexes were found soluble in dimethylformamide and dimethylsulphoxide but were insoluble in common organic solvents and water. They were thermally stable up to $\sim 250^{\circ} \mathrm{C}$ and then decomposed into a dark wet solid.

The template condensation of 2, 2-dihydroxyindane-1, 3-dione (ninhydrin) and 1, 2/1, 3-diaminobenzene in the presence of trivalent metal salts, in the molar ratio of 2:2:1 has been shown as follows:

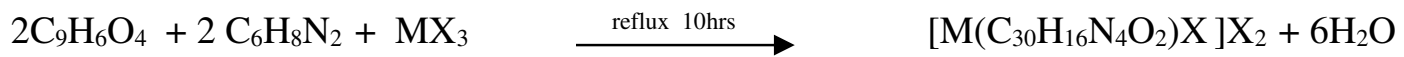

Where, $\mathrm{M}=\mathrm{Cr}$ (III), $\mathrm{Fe}(\mathrm{III})$ and $\mathrm{Co}(\mathrm{III}), \mathrm{X}=\mathrm{Cl}$

\section{RESULTS AND DISCUSSION}

The complexes have been characterized by elemental analyses, molar conductance, electronic spectra, magnetic measurements and IR spectral data. The microanalysis of $\mathrm{C}, \mathrm{H}$, and $\mathrm{N}$ was recorded at Elementar Vario EL III (Carlo Erba 1108). SAIF Chandigarh. The metal percentage in all complexes was estimated using EDTA method. A known quantity of the complexes was heated with a very small amount of concentrated hydrochloric acid and then repeatedly with concentrated nitric acid until all the organic matter was decomposed. The residue was dissolved in double distilled water or sometimes dilute hydrochloric acid was added to it and made up to known volume from which the metals were estimated by standard literature methods. Mostly $0.1 \mathrm{M}$ EDTA was used to determine the metal contents volumetrically using Eriochrome Black- T, Sulphosalicylic acid or Murexide as indicators. Analytical grade samples of organic compounds, solvents, and metal salts have been used throughout the investigations. Solvents were used as such as received and purified and dried as per requirement by standard methods.

The analytical data of trivalent macrocyclic complexes derived from 1,2-/1,3-diaminobenzene and ninhydrin has been given in Table-1-2 and complexes may be represented by the formulae: $\left[\mathrm{M}\left(\mathrm{C}_{30} \mathrm{H}_{16} \mathrm{~N}_{4} \mathrm{O}_{2}\right) \mathrm{Cl}\right] \mathrm{Cl}_{2}$; where $\mathrm{M}=\mathrm{Cr}(\mathrm{III}), \mathrm{Fe}(\mathrm{III})$ and $\mathrm{Co}(\mathrm{III})$. The test for anions was positive before and after decomposing the complexes indicating their presence inside as well as outside the coordination sphere. Conductivity measurements in dimethylsulphoxide indicated them to be 1:2 electrolytic in nature (130-170 $\left.\mathrm{ohm}^{-1} \mathrm{~cm}^{2} \mathrm{~mol}^{-1}\right)^{15}$. The molar conductance of complexes in DMSO solution at room temperature was measured on digital conductivity meter (HPG System, G3001) using dip type cell. The conductance values for different types of electrolyte in various solvents have already been reported.

\section{Infrared Spectra}

Infrared spectra of the complexes in the conventional region $\left(4000-667 \mathrm{~cm}^{-1}\right)$ were recorded on a Beckman IR-12 spectrophotometer using $\mathrm{KBr}$ /nujol mulls /pellets. These measurements were carried out at Department of Chemistry, Punjab University Chandigarh. Far infrared spectra $\left(650-200 \mathrm{~cm}^{-1}\right)$ were recorded using nujol mull on a Beckman IR-12 spectrophotometer.

A strong band appears at $\sim 1720 \mathrm{~cm}^{-1}$ which may be assigned to one carbonyl $>\mathrm{C}=\mathrm{O}$ group which is formed by dehydration of geminal hydroxyl groups present at 2,2 positions of the 2,2-dihydroxyindane1, 3-dione, due to heating. A pair of bands at $\sim 3200$ and $3250 \mathrm{~cm}^{-1}$ were also observed which correspond to $-\mathrm{NH}_{2}$ group present in infrared spectra of diaminobenzenes but were absent in the infrared spectra of all the metal complexes. A strong absorption band in the region $\sim 1595-1640 \mathrm{~cm}^{-1}$ may be attributed to the $v(-$ $\mathrm{C}=\mathrm{N}$-) group ${ }^{16}$ formed after the condensation of the carbonyl with an amino group. The lower values of $v(-\mathrm{C}=\mathrm{N}-)$ stretching frequency may be explained on the basis of drift of lone pair density of azomethine nitrogen towards the metal atom due to their coordination. These results provided strong evidence for the formation of the macrocyclic frame. The bands present in the range $\sim 1350-1000 \mathrm{~cm}^{-1}$ in all the complexes were assigned to $v(-\mathrm{C}-\mathrm{N}-)$ stretching vibrations. The presence of stretching bands at $\sim 1462$ and $\sim 1500$ 
$\mathrm{cm}^{-1}$ may be assigned to $>\mathrm{C}=\mathrm{C}<$ skeleton of benzenoid rings and a peak at $\sim 721 \mathrm{~cm}^{-1}$ was due to the $\mathrm{C}-\mathrm{H}$ deformation of meta substitution. In ortho-diaminobenzenes the value of $\mathrm{C}-\mathrm{H}$ deformation has changed its place to $771 \mathrm{~cm}^{-117}$. The spectra exhibit a ring breathing mode at $\sim 990 \mathrm{~cm}^{-1}$, an out- of- plane $v(\mathrm{C}-\mathrm{H})$ deformation at $\sim 810 \mathrm{~cm}^{-1}$, an in-plane $v(\mathrm{C}-\mathrm{C})$ deformation at $\sim 620 \mathrm{~cm}^{-1}$ and out- of- plane deformation at $\sim 410 \mathrm{~cm}^{-1}$, respectively ${ }^{18,19}$. The coordination of azomethine nitrogen to the central metal atom can be ascertained from the far IR data which showed bands in the region $\sim 420-470 \mathrm{~cm}^{-1}$ corresponding to $v(\mathrm{M}$ $\mathrm{N})$ vibrations ${ }^{20}$. The bands present at $\sim 290-310 \mathrm{~cm}^{-1}$ may be assigned as being due to $\mathrm{v}(\mathrm{M}-\mathrm{Cl})$ vibrations 20

\section{${ }^{1}$ H NMR Spectra}

The ${ }^{1} \mathrm{H}$ NMR spectra could not be obtained because the compounds were insoluble in common solvents and don't form a clear solution.

\section{Magnetic Measurements and Electronic Spectral Studies}

Electronic transitions occur between split' levels of the central atom giving rise to d-d or ligand field spectra. The spectral region where these occur spans the near infrared, visible and U.V. region. Ultraviolet: $50,000-26300 \mathrm{~cm}^{-1}$, Visible: $26300-12800 \mathrm{~cm}^{-1}$, near infrared: $12800-5000 \mathrm{~cm}^{-1}$. Electronic transitions occur in a very short time (about 10-15 sec.) and hence the atoms in a molecule do not have time to change position appreciably during the electronic transition. So the molecule will find itself with the same molecular configuration and hence the vibrational kinetic energy in the excited state remains the same as it had in the ground state at the moment of absorption. Frequently, transitions occur from the ground vibrational level of the ground electronic state to many different vibrational levels of particular excited electronic states. Such transitions may give rise to vibrational fine structure in the main peak of the electronic transition. Since all the molecules are present in the ground vibrational level, nearly all transitions that give rise to a peak in the absorption spectrum will arise from the ground electronic state. If the different excited vibrational levels are represented as $v 1, v 2$, etc., and the ground state as v0, the fine structure in the main peak of the spectrum is assigned to $v 0 \rightarrow v 0, v 0 \rightarrow v 1, v 0 \rightarrow v 2$ etc., vibrational states. The $v 0 \rightarrow v 0$ transition is the lowest energy (longest wavelength) transition ${ }^{21}$. The different excited vibrational levels are represented by the term symbols ${ }^{4} \mathrm{~B}_{1},{ }^{4} \mathrm{E}^{\mathrm{a}},{ }^{4} \mathrm{~A}_{2}$.

\section{Chromium (III) Complexes}

Magnetic moments of the chromium complexes were found in the range of 4.12-4.46 B.M at room temperature which was close to the predicted values for three unpaired electrons in the metal ion ${ }^{21}$. The electronic spectra of chromium(III) complexes show bands at $\sim 9100-9300 \mathrm{~cm}^{-1,} \sim 13000-13300 \mathrm{~cm}^{-1}$, $\sim 17550-18300 \mathrm{~cm}^{-1}, \sim 27,280 \mathrm{~cm}^{-1}$ and $\sim 34810 \mathrm{~cm}^{-1}$. However, these spectral bands cannot be interpreted in terms of four- or six- coordinated environment around the metal atom. The spectral bands were consistent with that of five- coordinated square-pyramidal chromium (III) complexes, whose structure has been confirmed with the help of X-ray measurements ${ }^{21}$. Thus, on the basis of the analytical data and electrolytic nature of these complexes, a five-coordinated square-pyramidal geometry may be assigned to these complexes. Thus, assuming the symmetry $\mathrm{C}_{4 \mathrm{v}}$ for these complexes, ${ }^{21}$ the various spectral bands may be assigned as ${ }^{4} \mathrm{~B}_{1} \rightarrow{ }^{4} \mathrm{E}^{\mathrm{a}},{ }^{4} \mathrm{~B}_{1} \rightarrow{ }^{4} \mathrm{~B}_{2},{ }^{4} \mathrm{~B}_{1} \rightarrow{ }^{4} \mathrm{~A}_{2}$ and ${ }^{4} \mathrm{~B}_{1} \rightarrow{ }^{4} \mathrm{E}^{\mathrm{b}}$.

\section{Iron(III) Complexes}

The magnetic moments of iron complexes were found in the range of 5.7-5.9 B.M., corresponding to the five unpaired electrons and was close to predicted high spin values for these metal ions ${ }^{22}$. The electronic spectra of iron(III) complexes showed various bands at $\sim 9830-9980 \mathrm{~cm}^{-1}, \sim 15500-15580 \mathrm{~cm}^{-1}, \sim 27500$ $27,700 \mathrm{~cm}^{-1}$ and were consistent with the range of spectral bands reported for five coordinate squarepyramidal iron(III) complexes ${ }^{23}$. Assuming $\mathrm{C}_{4 \mathrm{~V}}$ symmetry for these complexes, the various bands may be assigned as $d_{x y} \rightarrow d_{x z}, d_{y z}$ and $d_{x y} \rightarrow d_{z}{ }^{2}$. Any attempt to make accurate assignment was difficult due to interactions of the metal-ligand л-bond systems lifting the degeneracy of the $\mathrm{d}_{\mathrm{xz}}$ and $\mathrm{d}_{\mathrm{yz}}$ pair. 


\section{Cobalt (III) Complexes}

The magnetic moment of the complexes is 5.7-5.9 B.M indicating the electronic configuration to be $3 \mathrm{~d}^{6} 4 \mathrm{~s}^{0}$. This value is in the range reported for a high spin, square pyramidal geometry around the Co (III) ion. The values that appear for the absorption in the electronic spectrum $\left(18,800-18,200 \mathrm{~cm}^{-1}, 22,900 \mathrm{~cm}^{-}\right.$ ${ }^{1}$ and $39^{\prime} 000 \mathrm{~cm}^{-1}$ ) support high spin, square pyramidal geometry around Co (III) ion ${ }^{24}$. The strong absorption bands found at $18,000 \mathrm{~cm}^{-1}$ in the spectrum of the complexes may be due to a symmetryallowed ligand field transition. It may be an electron transfer band ${ }^{25}$.

Table-1: Analytical data of the trivalent chromium, iron and cobalt complexes derived from diaminobenzenes and ninhydrin.

\begin{tabular}{|c|c|c|c|c|c|c|}
\hline \multirow[t]{2}{*}{ S.No. } & \multicolumn{6}{|c|}{ Found (Calcd.) \% } \\
\hline & Complexes & $\mathrm{C}$ & $\mathrm{H}$ & $\mathrm{N}$ & $\mathrm{M}$ & Mol.Wt \\
\hline 1 & {$\left[\mathrm{Cr}\left(\mathrm{C}_{30} \mathrm{H}_{16} \mathrm{~N}_{4} \mathrm{O}_{2}\right) \mathrm{Cl}\right] \mathrm{Cl}_{2}^{\mathrm{a}}$} & $57.5(57.8)$ & $2.3(2.5)$ & $8.7(8.9)$ & $8.1(8.3)$ & 622.5 \\
\hline 2 & {$\left[\mathrm{Cr}\left(\mathrm{C}_{30} \mathrm{H}_{16} \mathrm{~N}_{4} \mathrm{O}_{2}\right) \mathrm{Cl}\right] \mathrm{Cl}_{2}{ }^{\mathrm{b}}$} & $57.6(57.8)$ & $2.2(2.5)$ & $8.7(8.9)$ & $8.2(8.3)$ & 622.5 \\
\hline 3 & {$\left[\mathrm{Fe}\left(\mathrm{C}_{30} \mathrm{H}_{16} \mathrm{~N}_{4} \mathrm{O}_{2}\right) \mathrm{Cl}\right] \mathrm{Cl}_{2}{ }^{\mathrm{a}}$} & $57.2(57.4)$ & $2.4(2.5)$ & $8.6(8.9)$ & $8.8(8.9)$ & 626.5 \\
\hline 4 & {$\left[\mathrm{Fe}\left(\mathrm{C}_{30} \mathrm{H}_{16} \mathrm{~N}_{4} \mathrm{O}_{2}\right) \mathrm{Cl}\right] \mathrm{Cl}_{2}{ }^{\mathrm{b}}$} & $57.1(57.4)$ & $2.3(2.5)$ & $8.7(8.9)$ & $8.7(8.9)$ & 626.5 \\
\hline 5 & {$\left[\mathrm{Co}\left(\mathrm{C}_{30} \mathrm{H}_{16} \mathrm{~N}_{4} \mathrm{O}_{2}\right) \mathrm{Cl}\right] \mathrm{Cl}_{2}{ }^{\mathrm{a}}$} & $56.5(57.2)$ & $2.4(2.5)$ & $8.6(8.9)$ & $9.0(9.3)$ & 628.5 \\
\hline 6 & {$\left[\mathrm{Co}\left(\mathrm{C}_{30} \mathrm{H}_{16} \mathrm{~N}_{4} \mathrm{O}_{2}\right) \mathrm{Cl}\right] \mathrm{Cl}_{2}{ }^{\mathrm{b}}$} & $57.0(57.2)$ & $2.3(2.5)$ & $8.7(8.9)$ & $9.1(9.3)$ & 628.5 \\
\hline
\end{tabular}

$\mathrm{a}$ - 1, 2-diaminobenzene, $\mathrm{b}$ - 1, 3-diaminobenzene

Table-2: Analytical data of the trivalent chromium, iron and cobalt complexes derived from diaminobenzenes and

\begin{tabular}{|c|c|c|c|c|c|}
\hline S. No. & Complexes & Color & $\begin{array}{l}\text { Molar Conductance } \\
\left(\mathrm{ohm}^{-1} \mathrm{~cm}^{2} \mathrm{~mol}^{-1}\right)\end{array}$ & $\begin{array}{l}\text { Yield } \\
(\%)\end{array}$ & $\mu_{\mathrm{eff}}$ \\
\hline 1 & {$\left[\mathrm{Cr}\left(\mathrm{C}_{30} \mathrm{H}_{16} \mathrm{~N}_{4} \mathrm{O}_{2}\right) \mathrm{Cl}\right] \mathrm{Cl}_{2}^{\mathrm{a}}$} & Shiny dirty green & 132 & $45 \%$ & 4.12 \\
\hline 2 & {$\left[\mathrm{Cr}\left(\mathrm{C}_{30} \mathrm{H}_{16} \mathrm{~N}_{4} \mathrm{O}_{2}\right) \mathrm{Cl}\right] \mathrm{Cl}_{2}{ }^{\mathrm{b}}$} & Dark green Powder & 138 & $42 \%$ & 4.49 \\
\hline 3 & {$\left[\mathrm{Fe}\left(\mathrm{C}_{30} \mathrm{H}_{16} \mathrm{~N}_{4} \mathrm{O}_{2}\right) \mathrm{Cl}\right] \mathrm{Cl}_{2}^{\mathrm{a}}$} & Shiny olive green & 168 & $43 \%$ & 5.81 \\
\hline 4 & {$\left[\mathrm{Fe}\left(\mathrm{C}_{30} \mathrm{H}_{16} \mathrm{~N}_{4} \mathrm{O}_{2}\right) \mathrm{Cl}\right] \mathrm{Cl}_{2}^{\mathrm{b}}$} & Greenish brown & 166 & $43 \%$ & 5.70 \\
\hline 5 & {$\left[\mathrm{Co}\left(\mathrm{C}_{30} \mathrm{H}_{16} \mathrm{~N}_{4} \mathrm{O}_{2}\right) \mathrm{Cl}\right] \mathrm{Cl}_{2}{ }^{\mathrm{a}}$} & Shiny dark grey & 152 & $47 \%$ & 5.70 \\
\hline 6 & {$\left[\mathrm{Co}\left(\mathrm{C}_{30} \mathrm{H}_{16} \mathrm{~N}_{4} \mathrm{O}_{2}\right) \mathrm{Cl}\right] \mathrm{Cl}_{2}{ }^{\mathrm{b}}$} & Black powder & 154 & $43 \%$ & 5.61 \\
\hline
\end{tabular}

$\mathrm{a}$ - 1, 2-diaminobenzene, $\mathrm{b}$ - 1, 3-diaminobenzene

\section{Proposed Structure}

Therefore, based on various physicochemical techniques such as elemental analyses, molar conductivity measurements, magnetic susceptibility measurements, electronic and infrared spectral studies, a squarepyramidal structure as shown in Fig.-1 may be proposed for all the trivalent metal complexes.

\section{Antifungal Activity Test of Trivalent Metal Complexes Derived from 2, 2-Dihydroxyindane-1, 3- dione (ninhydrin) and 1, 2-/1, 3-diaminobenzene}

Panama disease or Agent Green, is a fungus that causes Fusarium wilt disease in more than a hundred species of cotton plants. This fungus breaks the conducting tissue of the cotton plant which leads to leaf wilting, yellowing and eventually death of the plant. Alternaria alternata is another fungus causing leaf spot and other diseases on over 380 host species. It also causes upper respiratory tract infections in AIDS patients and asthma in people with sensitivity. The compounds synthesized were tested on these two; leaf fungus Alternaria alternate and root fungus Fusarium oxysporum of the cotton plants. The antifungal activity of the Compounds was screened by spore germination inhibition technique. ${ }^{26,27}$.

\section{Isolation and Maintenance}

Diseased samples of cotton leaves and roots were collected from experimental areas of Punjab Agricultural University, Ludhiana, and washed with running tap water for 5-10 minutes. The infected 
parts were cut into small pieces using a sterilized blade. Then these were sterilized with mercuric chloride solution $(0.1 \%)$ for one minute followed by washings them trice with sterilized distilled water. Sterilized infected samples were transferred to dextrose agar (PDA) medium (200 g peeled potato, $20 \mathrm{~g}$ dextrose and $20 \mathrm{~g}$ agar in 1-liter water) slants under aseptic conditions. In order to get a good growth of the fungi, test tubes were incubated at $25 \pm 1^{\circ} \mathrm{C}$. The culture so obtained were purified and maintained by further subculturing on PDA slants and keeping them in the refrigerator.

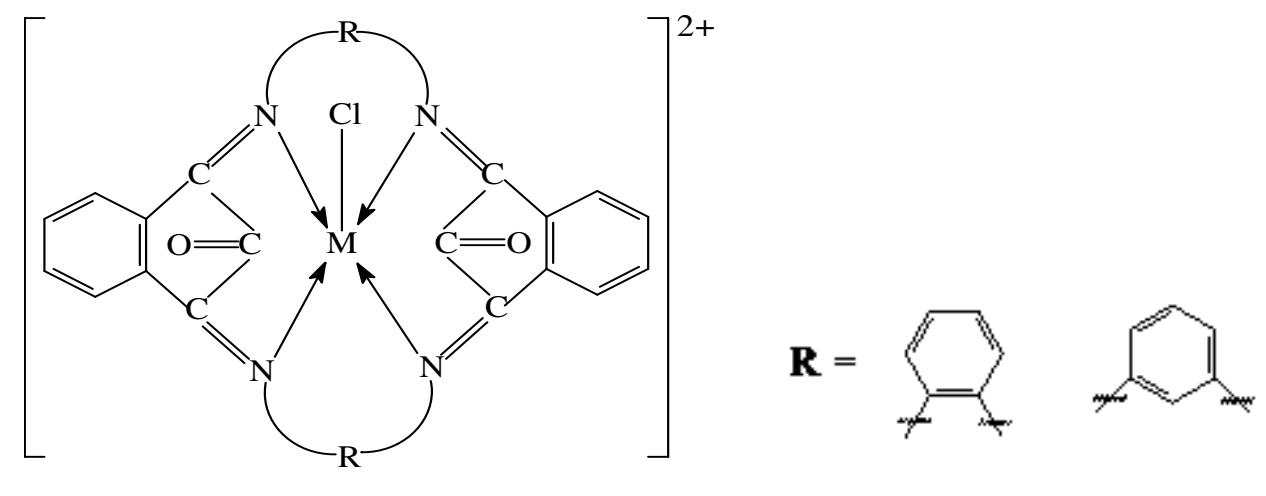

$\mathrm{M}=\mathrm{Cr}(\mathrm{III}), \mathrm{Fe}$ (III), $\mathrm{Co}$ (III)

\section{Preparation of Stock Solution}

Fig.-1

The stock solution of each compound and two standard fungicides viz. Indofil M-45 (75\% manganese ethylene bis dithiocarbamate $+2 \%$ zinc ion) and Bavistin 50WP (methyl benzimidazol-2-yl carbamate) were prepared by dissolving each chemical $(20 \mathrm{mg})$ in DMSO and volume were made to $10 \mathrm{ml}$ with sterilized water. Tween-20 was added to get a clear solution. The stock solution of $2000 \mathrm{ppm}$ of each chemical thus prepared on active ingredient basis was kept in refrigerator until use. The required dilution of $1000,500,250,100,50,25$ and 10 ppm were subsequently made from the stock solution by adding distilled water as and when required.

\section{Spore Germination and Inhibition Technique}

Sterilized distilled water was added to ten-day old cultures of fungi taken from PDA slants to form the suspension of spores. After thoroughly shaking the tube, the suspension was filtered through three layers of sterilized cheese cloth under aseptic conditions to remove mycelial and agar bits. Standardized spore suspension $\left(1 \times 10^{6}\right.$ spores $\left./ \mathrm{ml}\right)$ was made with the help of haematocytometer. Double strength concentration of the compounds was prepared and used as desired. Small droplets $(0.02 \mathrm{ml})$ of the spore suspension in equal quantity with a solution of the test compound were seeded in the cavity of cavity slides. These slides were placed in petriplates lined with moist filter paper. The petriplates containing cavity slides were incubated at $25 \pm 1^{\circ} \mathrm{C}$ for 24 hours. The germination of the spores was calculated by the following formula:

$$
\% \text { spore germination inhibition }=\frac{\begin{array}{l}
\text { spore germination } \\
\text { in control }
\end{array}-\begin{array}{c}
\text { spore germination } \\
\text { in treatment }
\end{array}}{\begin{array}{l}
\text { spore germination } \\
\text { in control }
\end{array}} \times 100
$$

Indofil M-45 and Bavistin 50WP were used as a check to compare the activity of the compounds. The antifungal activity has been expressed in terms of $\mathrm{ED}_{50}$ values i.e. effective dose to inhibit $50 \%$ spore germination.

\section{RESULTS AND DISCUSSION}

All the synthesized trivalent metal complexes were subjected to tests for antifungal activities. Their percentage inhibition in $\mathrm{mg} / \mathrm{l}$ was determined in different dilutions from where their $\mathrm{ED}_{50}$ values where calculated. 


\section{Alternaria Alternate}

Table-3 showed the percentage inhibition in $\mathrm{mg} / \mathrm{ml}$ against Alternaria alternata and Table 4 showed the percentage inhibition in $\mathrm{mg} / \mathrm{ml}$ against Fusarium oxysporium using the trivalent metal complexes of 1,211,3-diaminobenzene and 2,2-dihydroxyindane-1,3-dione. When compared with standard fungicide, Indofil M-45 whose $\mathrm{ED}_{50}$ value was found to be 37 , it was observed none of the complexes showed fungicidal properties against A. alternata.

\section{Fusarium Oxysporum}

Table- 4 showed the percentage inhibition in $\mathrm{mg} / \mathrm{ml}$ against Fusarium oxysporium using the trivalent metal complexes of 1, 2-/1, 3-diaminobenzene and 2, 2-dihydroxyindane-1, 3-dione. Bavistin 50WP was used as a standard fungicide to compare the efficacy of synthesized trivalent metal complexes. Its $\mathrm{ED}_{50}$ value was found to be 7 . Most of the compound inhibits growth to a very less extent. [Fe $\left(\mathrm{C}_{30} \mathrm{H}_{16} \mathrm{~N}_{4} \mathrm{O}_{2}\right)$ $\mathrm{Cl}] \mathrm{Cl}_{2}$ is an effective antifusarium complex only.

Table-3: Efficacy of synthesized trivalent cobalt, chromium and iron complexes derived from 2, 2-dihydroxyindane1,3-dione and diaminobenzenes against Alternaria alternata.

\begin{tabular}{|c|c|c|c|c|c|c|c|c|}
\hline \multirow[t]{2}{*}{ S.No. } & \multirow[t]{2}{*}{ Compound } & \multicolumn{6}{|c|}{ Percent inhibition in $\mathrm{mg} / \mathrm{ml}$} & \multirow{2}{*}{$\frac{\mathrm{ED}_{50}}{(\mathrm{mg} / \mathrm{ml})}$} \\
\hline & & 1000 & 500 & 250 & 100 & 50 & 25 & \\
\hline 1 & {$\left[\mathrm{Cr}\left(\mathrm{C}_{30} \mathrm{H}_{16} \mathrm{~N}_{4} \mathrm{O}_{2}\right) \mathrm{Cl} \mathrm{Cl}_{2}{ }^{\mathrm{a}}\right.$} & 38 & 32 & 20 & 19 & 11 & 3 & * \\
\hline 2 & {$\left[\mathrm{Cr}\left(\mathrm{C}_{30} \mathrm{H}_{16} \mathrm{~N}_{4} \mathrm{O}_{2}\right) \mathrm{Cl} \mathrm{Cl}_{2}{ }^{\mathrm{b}}\right.$} & 40 & 36 & 29 & 20 & 12 & 5 & $*$ \\
\hline 3 & {$\left[\mathrm{Fe}\left(\mathrm{C}_{30} \mathrm{H}_{16} \mathrm{~N}_{4} \mathrm{O}_{2}\right) \mathrm{Cl}\right] \mathrm{Cl}_{2}^{\mathrm{a}}$} & 33 & 22 & 19 & 13 & 13 & 4 & * \\
\hline 4 & {$\left[\mathrm{Fe}\left(\mathrm{C}_{30} \mathrm{H}_{16} \mathrm{~N}_{4} \mathrm{O}_{2}\right) \mathrm{Cl}\right] \mathrm{Cl}_{2}{ }^{\mathrm{b}}$} & 37 & 25 & 19 & 15 & 13 & 6 & $*$ \\
\hline 5 & {$\left[\mathrm{Co}\left(\mathrm{C}_{30} \mathrm{H}_{16} \mathrm{~N}_{4} \mathrm{O}_{2}\right) \mathrm{Cl}\right] \mathrm{Cl}_{2}{ }^{\mathrm{a}}$} & 46 & 38 & 22 & 15 & 10 & 8 & $*$ \\
\hline 6 & {$\left[\mathrm{Co}\left(\mathrm{C}_{30} \mathrm{H}_{16} \mathrm{~N}_{4} \mathrm{O}_{2}\right) \mathrm{Cl}\right] \mathrm{Cl}_{2}{ }^{\mathrm{b}}$} & 55 & 44 & 40 & 35 & 15 & 8 & * \\
\hline & INDOFIL M-45 & 100 & 100 & 95 & 77 & 62 & 40 & 37 \\
\hline
\end{tabular}

$\mathrm{a}$ - 1, 2-diaminobenzene $\mathrm{b}$ - 1, 3-diaminobenzene

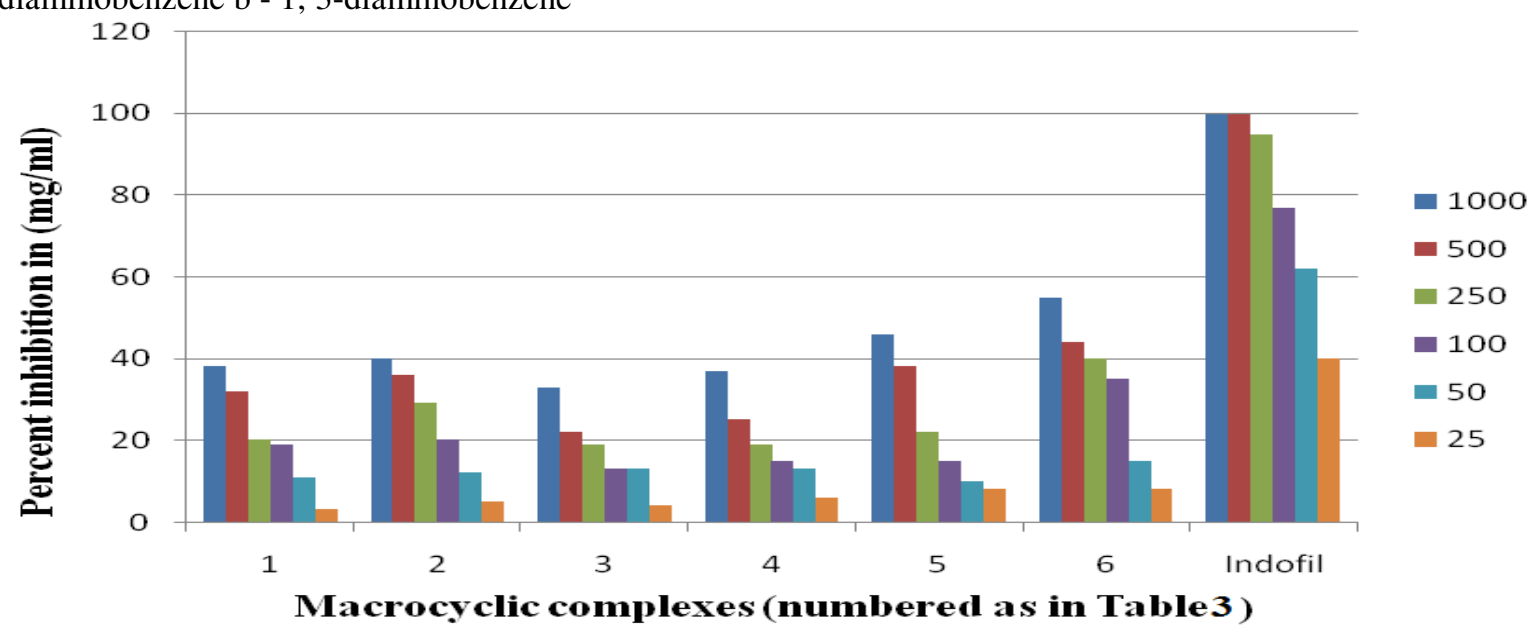

Fig.-2: Bar Graph representation of the above data given in Table-3

Table-4: Efficacy of synthesized trivalent chromium, cobalt and iron complexes derived from 2, 2-dihydroxyindane1,3-dione and diaminobenzenes against Fusarium oxysporium.

\begin{tabular}{|c|c|c|c|c|c|c|c|c|c|c|}
\hline \multirow[t]{2}{*}{ S. No. } & \multirow[t]{2}{*}{ Compound } & \multicolumn{8}{|c|}{ Percent inhibition in $\mathrm{mg} / \mathrm{ml}$} & $\mathrm{ED}_{50}$ \\
\hline & & 1000 & 500 & 250 & 100 & 50 & 25 & 10 & 5 & $(\mathrm{mg} / \mathrm{ml})$ \\
\hline 1 & {$\left[\mathrm{Cr}\left(\mathrm{C}_{30} \mathrm{H}_{16} \mathrm{~N}_{4} \mathrm{O}_{2}\right) \mathrm{Cl} \mathrm{Cl}_{2}^{\mathrm{a}}\right.$} & 36 & 19 & 17 & 14 & 10 & 4 & 0 & 0 & * \\
\hline 2 & {$\left[\mathrm{Cr}\left(\mathrm{C}_{30} \mathrm{H}_{16} \mathrm{~N}_{4} \mathrm{O}_{2}\right) \mathrm{Cl}\right] \mathrm{Cl}_{2}{ }^{\mathrm{b}}$} & 35 & 18 & 18 & 12 & 10 & 7 & 0 & 0 & * \\
\hline
\end{tabular}


RASĀYAN J. Chem.

Vol. 11 | No. 2 |694 - 701 | April - June | 2018

\begin{tabular}{c|l|c|c|c|c|c|c|c|c|c}
\hline 3 & {$\left[\mathrm{Fe}\left(\mathrm{C}_{30} \mathrm{H}_{16} \mathrm{~N}_{4} \mathrm{O}_{2}\right) \mathrm{Cl}_{\mathrm{Cl}}{ }_{2}^{\mathrm{a}}\right.$} & 80 & 63 & 52 & 37 & 25 & 12 & 10 & 3 & 280 \\
\hline 4 & {$\left[\mathrm{Fe}\left(\mathrm{C}_{30} \mathrm{H}_{16} \mathrm{~N}_{4} \mathrm{O}_{2}\right) \mathrm{Cl}_{\mathrm{Cl}_{2}{ }^{\mathrm{b}}}\right.$} & 95 & 79 & 64 & 61 & 51 & 47 & 35 & 10 & 62 \\
\hline 5 & {$\left[\mathrm{Co}\left(\mathrm{C}_{30} \mathrm{H}_{16} \mathrm{~N}_{4} \mathrm{O}_{2}\right) \mathrm{Cl}_{\mathrm{Cl}_{2}{ }^{\mathrm{a}}}\right.$} & 39 & 15 & 10 & 10 & 8 & 5 & 0 & 0 & $*$ \\
\hline 6 & {$\left[\mathrm{Co}\left(\mathrm{C}_{30} \mathrm{H}_{16} \mathrm{~N}_{4} \mathrm{O}_{2}\right) \mathrm{Cl} \mathrm{Cl}_{2}{ }^{\mathrm{b}}\right.$} & 35 & 20 & 18 & 15 & 10 & 5 & 0 & 0 & $*$ \\
\hline & Bavisitin & 100 & 100 & 100 & 100 & 92 & 75 & 60 & 42 & 7 \\
\hline
\end{tabular}

a-1, 2-diaminobenzene b -1, 3-diaminobenzene

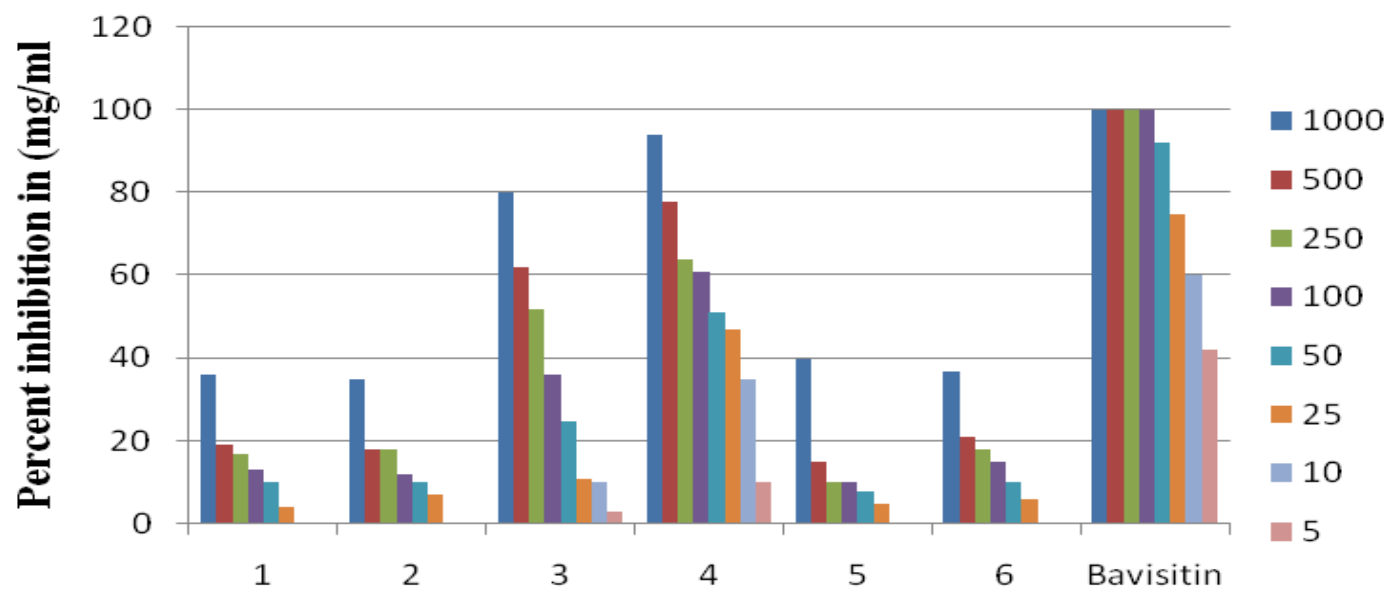

Macrocyclic complexes (numbered as in Table 4)

Fig.-3: Bar Graph representation of the above data given in Table-4

\section{REFERENCES}

1. T.W. Hambley, L.F. Lindoy, J.R. Rimer, P. Jumer, A.N.W. Cooper, J. Chem. Soc. Dalton Trans. 614(2001).

2. K.Y. Choi, K.M. Chun, I.H. Suh, Polyhedron 20, 57(2001).

3. S. Chandra, K. Gupta, Transition Met. Chem. 27,196(2002).

4. R.R. Fenton, R. Gauci, P.C. Junk, L.F. Lindoy, R.C. Luckay, V. Meehan, J.R. Price, P.Tumer, J. Chem. Soc. Dalton Trans. 2185(2002).

5. E.Q. Gao, H.Y. Sun, D.Z. Liao, Z.H. Jiang, S.P. Yan, Polyhedron, vol. 21, 359(2002).

6. A. Chaudhary, S. Dave, R. Swaroop, R.V. Singh, J. Indian Chem. Soc. 79, 371(2002).

7. R.R. Gagne, C.I. Spiro, T.J. Smith, W.R. Hamanu, W.R. Thies, J. Am. Chem. Soc.103, 4073(1981).

8. R.D. Jons, D.A. Summervile, F. Basolo, Chem. Rev. 79, 139(1979).

9. L.R. Milgrom, "The colours of Life: An Introduction to the Chemistry of Porphyrins and Related Compounds", Oxford University Press, New York(1997).

10. E.C. Constable 1999, Coordination Chemistry of Macrocyclic Complexes, Oxford University Press, New York; K. Gloe (Ed.) "Macrocyclic Chemistry, Current Trends and Future Perspective", Springer, Netherlands (2005); K.Y. Choi, K.M. Chun and I.H. Suh, Polyhedron, 20, 57(2001).

11. G. Cross, J.P. Costs, Acad. CRSC, Paris 294, 173(1982);

12. M.D. Hobday and T.D. Smith, Coord. Chem. Rev., 9, 311(1972).

13. L.F. Lindoy and S.E. Livingstone, Coord. Chem. Rev., 2, 173(1967).

14. N.F. Curtis, J. Chem. Soc., 4409 (1960); Coord. Chem. Rev, 3, 3(1968).

15. W.J. Geary, Coord. Chem. Rev., 7, 8(1971)

16. S. Chandra and R. Gupta, Transition Met. Chem., 31, 147(2006); S. Balasubramanian and C.N. Krishnan, Indian J. Chem., 24A, 608(1985); Transition Met. Chem.29, 523(2004). 
RASĀYAN J. Chem.

Vol. 11 | No. 2 |694 - 701 | April - June | 2018

17. K. Nakamoto 1997, Infrared Spectra of Inorganic and Coordination Compounds, part B, $\mathbf{5}^{\text {th }}$ edition, Wiley Inter Science, New York

18. D.P. Singh, V. Malik, K. Kumar, C. Sharma and K.R. Aneja, Spectrochim. Acta Part A, 76, 45(2010); Singh, D.P.; Mehani née Chopra, Rimpi, Pesticide-Biochemistry and Physiology, 98,110-114(2010)

19. J. Gazo, I.B. Bersuker, J. Garaj, M. Kabesova, J. Kohout, H. Langeriderova, M.Melnik, M. Serator, F. Valach, Coord. Chem. Rev. 21, 253 (1976). Singh, D.P.; Kumar, K.; Mehani née Chopra, Rimpi, Spectrochimica Acta Part A: Molecular and Bimolecular Spectroscopy, 78, 629(2011).

20. J.R. Ferraro 1997, "Low Frequency Vibrations of Inorganic and Co-Ordination Compounds", Part B, $5^{\text {th }}$ Edition, Wiley Interscience, New York

21. D.P. Singh and Rimpi Mehani née Chopra, Rasayan J. Chem., 2, 633(2009); D.P. Singh and Rimpi Mehani née Chopra Rasayan J. Chem., 1, 93(2008)

22. J.S. Wood, Prog. Inorg. Chem., 16, 227 (1972)

23. B.N. Figgis 1966, The Magnetic Properties of the Complex Ions. Introduction to ligand fields, $\mathbf{1}^{\text {st }}$ Ed., Wiley interscience:New York, pp 272-281

24. A.B.P. Lever 1984, Inorganic Electronic Spectroscopy, $\mathbf{2}^{\text {nd }}$ ed., Elsevier, Amsterdam, .

25. T.A. Khan, S. Naseem, S.N. Khan, A.U. Khan and M. Shakir, Spectrochim. Acta. A, 73, 622 (2009)

26. K.A. Jensen and C.K. Jorgensen, Acta. Chem. Scand., 19, 451 (1965)

27. Y.L. Nene, P.N. Thapliyal, Fungicides in Plant Disease Control, Oxford and IBH publishing Co., New Delhi, 1993, p. 525.

28. Electronic (Absorption) Spectra of 3d Transition Metal Complexes, S. Lakshmi Reddy, Tamio Endo Siva Reddy, DOI: $10.5772 / 50128$

[RJC-1953/2018] 